\title{
The Role Of Mobile Money In Moderating FinanCial Exclusion A Tanzanian Experience
}

\author{
Deogratus Joseph Mhella
}

University Of Bristol, United Kingdom

KEY WORDS

Financial Inclusion

Financial Exclusion

Mobile Money

Moderation of Financial

Exclusion

Tanzania

Deogratius Mhella

Banks and Digital

Financial Services
ABSTRACT

Prior to the advent of mobile money, the banking sector in most of the developing countries excluded certain segments of the population. The excluded populations were deemed as a risk to the banking sector. The banking sector did not work with cash stripped and financially disenfranchised people. Financial exclusion persisted to incredibly higher levels. Those excluded did not have bank accounts, savings in financial institutions, access to credit, loans, and insurance services. The advent of mobile money moderated the very factors of financial exclusion that the banks failed to resolve. This paper explains how mobile money moderates the factors of financial exclusion that the banks and microfinance institutions have always failed to moderate. The paper seeks to answer the following research question: 'How has mobile money moderated the factors of financial exclusion that other financial institutions failed to resolve between 1960 and 2008? Tanzania has been chosen as a case study to show how mobile has succeeded in moderating financial exclusion in the period after 2008.

\section{GLOBAL KNOWLEDGE




\section{Introduction}

$\mathrm{T}$ his paper explores the role of mobile money in moderating financial exclusion and in supporting financial inclusion. Mobile money has also been credited with changing how the banking sector operates (Aron, 2018; USAID, 2010). The banks have always been there, and they have provided formal financial services. However, the higher levels of financial exclusion have remained in Tanzania (FinScope, 2006; FinScope, 2009; FinScope, 2013a, FinScope, 2013b). The issue also caught the attention of many innovators who sought to resolve it. As a result, mobile money technology was introduced to increase financial inclusion. Mobile Money Operators (MNOs) entered the financial ecosystem and had since then provided mobile money services. This has been key to moderating financial exclusion. Hence, the scope of the article is twofold. Firstly, it introduces mobile money and its role in supporting financial exclusion and inclusion. Secondly, it illustrates how mobile money moderates the factors of financial exclusion in Tanzania. By demonstrating how mobile money has moderated financial exclusion in Tanzania, I also show how the MNOs change the provision of formal financial services, and by doing so, I argue that they facilitate the moderation of some factors of financial exclusion. Most studies have been conducted to show increasing levels of financial inclusion through mobile money (GSMA, 2016; GSMA, 2017). However, how mobile money moderates the factors of financial exclusion (in aiding the transformation of the banking sector) has very few studies conducted in Tanzania (InterMedia, 2014). There is this gap, and this article tries to address it.

The article consists of five sections as follows: Section 1 introduces the article. Section 2 introduces the brief history of mobile money both at global and national levels. Section 3 presents the methodology. Section 4 presents the theoretical assumptions and analyses the qualitative findings. Section 5 presents the conclusions.

\section{Brief History and Mobile Money context at both Global and National Levels}

\subsection{Mobile Money: Origins and Definition}

What is mobile money? According to AFI (2012):

Mobile money is a mobile-based transactional service that can be transferred electronically using mobile networks. A mobile issuer may, depending on local law and the business model, be an MNO or a third party such as a bank. Often used synonymously with 'mobile financial services'.

Also, there are other known definitions. According to UNCTAD (2012), mobile money refers to money stored using a 'Subscriber Identity Model' (SIM) card in a mobile phone as an identifier as opposed to an account in conventional banking. FinScope (2013) considers mobile money as an innovation that enhances financial inclusion. Mobile money, therefore, is kept in value issued by a Mobile Network Operator (MNO) or a bank and is kept in a value account on the SIM within the mobile phone which is also used to facilitate the transfer or payments. Under normal circumstances, the money is stored elsewhere, for instance, in a trust account in a bank, and the balance on the value can be accessed via the mobile phone and can be used to make instant transfers or payments. Mobile money services, therefore, need not be confused with 'mobile banking' services. According to GSMA (2016), mobile banking is essentially banking services delivered through a mobile phone. In this case, the principles of banking and the products, remain the same through the provider of the service (the bank), however mobile phones become the channel for delivery. For this study, I will use the AFI (2012) definition.

Mobile Money, as we know it today, was introduced in Tanzania in 2008 by Vodacom after a successful launch in Kenya the previous year. Tanzania's e-fulusi and 'Mobipawa' platform are also credited for starting the mobile money innovation in Tanzania. Since 2008 mobile money has significantly grown, and it is estimated that about one-third of GDP transactions in Tanzania passes through mobile financial services. 


\subsection{Mobile Money at the Global Level}

There are institutions at the global level that facilitate mobile money rules, policies, regulations, and innovations. According to GSMA (2016:27), in 2008 the GSMA established a mobile money program for the unbanked people, initially funded by the Bill and Melinda Gates Foundation. Furthermore, in 2011 the Bill and Melinda Gates Foundation through its Financial Services for the Poor (FSP) Program which was established in 2005, supported investments in digital finance and global advocacy. According to AFI (2012), the AFI's Mobile Financial Services Working Group (MFSWG) assists policymakers and regulators in the financial sectors to establish a conducive policy and regulatory environment which expands the reach of mobile money services and enhances financial inclusion. Also, GSMA (2016:27) asserts that in 2012, the United Nations (UN) launched the Better Than Cash Alliance (BTCA) to support the digitization of cash payments supported by various donors.

GSMA (2016b) also lists global institutions setting the financial service standards and the global standards-setting bodies. Firstly, the Committee on Payments and Market Infrastructure (CPMI), also known as, the Committee on Payments and Settlement Systems assists with regulatory issues. It proposes functional and non-discriminatory regulations, as well as, proportionate and adjusted regulations depending on the risks that each service poses. Secondly, the Basel Committee on Banking Supervision provides a platform for central banks to discuss banking supervision issues. Thirdly, the Financial Action Task Force (FATF) works on financial exclusion and money laundering and terrorist financing issues. It incorporates AntiMoney Laundering and Counter-Financing of Terrorism (AML/CFT) systems as well as riskbased approaches. Fourthly, the International
Association of Deposit Insurers deals with insurance issues.

Moreover, in 2014 the UN Capital Development Fund (UNCDF) launched Mobile Money for the Poor (MM4P) to help increase branchless and mobile financial services (GSMA: 2016:27). Likewise, the World Bank's Taskforce on Payment Aspects of Financial Inclusion (PAFI) supported mobile money and worked to promote access to digital payment services, raising awareness of banking benefits to generate new openings of bank accounts (BIS, 2015). Mobile money gained more support when the UN Sustainable Development Goals (SDGs) were launched, and according to GSMA (2016:27) mobile money "poised to contribute to 11 of the 17 SDGs".

According to Ghazizadeh (2012), the introduction of the Global System for Mobile Communications (GSM) has helped the growth of wireless communication. The 'Enhanced Data Rate for GSM Evolution' (EDGE) and the 'General Packet Radio Service' (GPRS) were technologies that offered benefits such as saving costs for accessing data networks. They also utilized the IPbased networks. Likewise, the 3rd Generation (3G) technology met the specifications of the International Telecommunications Union. Furthermore, the Universal Mobile Telecommunications System (UMTS) technology provided different platforms and network infrastructure enabling telecoms to offer a variety of services to customers including mobile money. GSMA (2018:18) predicts that 4G will take the lead by 2019 and that $5 \mathrm{G}$ will move from trials to commercialization as well. As technology evolves, it becomes easier for mobile money to transform financial services.

From Table 1, Sub- Saharan Africa has more registered mobile money accounts of which more than 100 registered accounts were active in 2016. This trend underlines the importance of mobile money in Africa. 
Table 1.

Mobile Money: Number of Registered and Active Customers, by Region

(Recent 90 days Active Accounts, Dec. 2016)

\begin{tabular}{|l|c|c|}
\hline \multicolumn{1}{|c|}{ Region } & $\begin{array}{c}\text { Registered Accounts (in } \\
\text { Millions) }\end{array}$ & $\begin{array}{c}\text { Active Accounts (in } \\
\text { Millions) }\end{array}$ \\
\hline Europe and Central Asia & 10.4 & 1.4 \\
\hline Middle East and North Africa & 44.1 & 13.3 \\
\hline Latin America and the Caribbean & 23.0 & 10.8 \\
\hline Sub-Saharan Africa & 277.4 & 100.1 \\
\hline South Asia & 164.2 & 40.4 \\
\hline East Asia and Pacific & 36.6 & 7.1 \\
\hline
\end{tabular}

Source: Table by Author, Source: GSMA (2016:17).

Graph 1.

Growth of Registered and Active Mobile Money Accounts

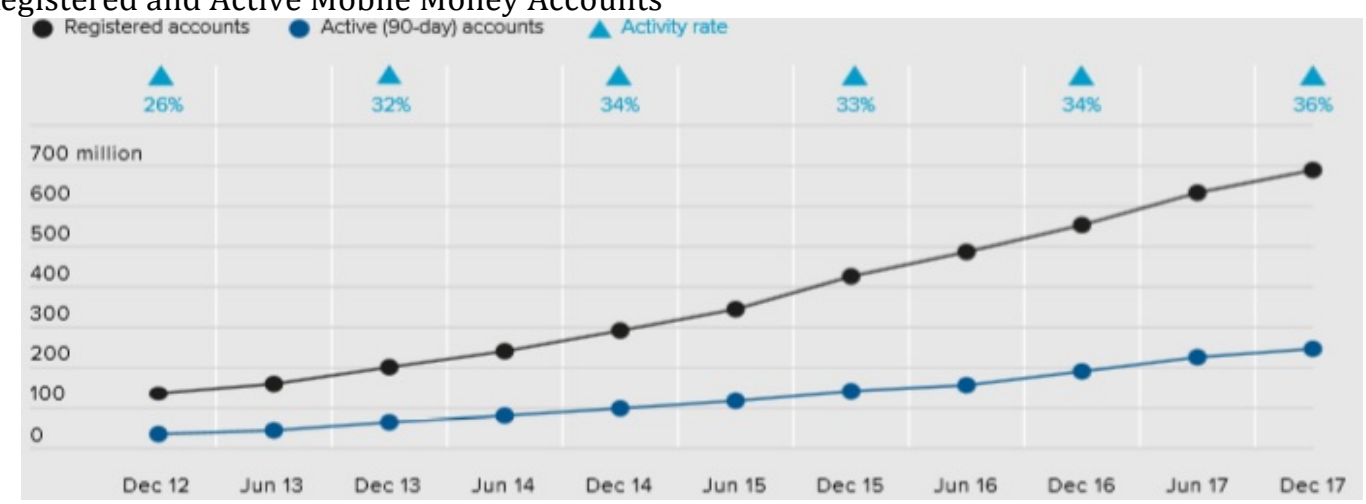

Source: GSMA (2016:1)

Graph 1 shows the growth of mobile accounts across the world, with active accounts growing at a very slow pace. Table 2 shows the potential for the growth of mobile subscriptions in Africa, which may increase the use of mobile money services. Growth is slow in developed mobile markets nearly approaching saturation. Donner (2008) found more mobile phone possessions than bank accounts in the world. According to GSMA (2018:12), there were more than 5 billion unique mobile subscribers in the world at the end of 2017.

Table 2.

Unique Mobile Subscriber Penetration (\%age of Population)

\begin{tabular}{|l|c|}
\hline \multicolumn{1}{|c|}{ Region } & Percentage in 2017 \\
\hline North America & $84 \%$ \\
\hline Europe & $85 \%$ \\
\hline Latin America & $67 \%$ \\
\hline Sub-Saharan Africa & $44 \%$ \\
\hline Middle East and North Africa & $62 \%$ \\
\hline Asia Pacific & $67 \%$ \\
\hline Commonwealth of Independent States (CIS) & $80 \%$ \\
\hline
\end{tabular}

Source: Author Using GSMA (2018:13) 
Table 3.

An Overview of the Mobile Ecosystem

\begin{tabular}{|c|c|c|c|c|c|}
\hline \multicolumn{6}{|c|}{ December 2012 Vs. December 2017. Breakdown of Transactions per Average Customer } \\
\hline \multicolumn{2}{|c|}{ Incoming Transactions } & \multicolumn{2}{|c|}{ Circulating Value } & \multicolumn{2}{|c|}{ Outgoing Transactions } \\
\hline $2012-88.1 \%$ & $2017-75.4 \%$ & $2012-94.4 \%$ & $2017-91.2 \%$ & $2012-81.3 \%$ & $73.8 \%$ \\
\hline $\begin{array}{l}\text { Cash in } 88.1 \% \\
\text { Bank-to wallet } 1 \% \\
\text { Bulk disbursements } \\
10.3 \% \\
\text { International } \\
\text { remittances } 0.6 \%\end{array}$ & $\begin{array}{l}\text { Cash-in } 75.4 \% \\
\text { Bank-to wallet } 9.2 \% \\
\text { Bulk disbursements } \\
14.3 \% \\
\text { International } \\
\text { remittances } 1.1 \%\end{array}$ & $\begin{array}{l}\text { P2P transfer } 94.4 \% \\
\text { Merchant payment } 5.6 \%\end{array}$ & $\begin{array}{l}\text { P2P 91.2\% } \\
\text { Merchant payment } 8.8 \%\end{array}$ & $\begin{array}{l}\text { Cash-out } 8.3 \% \\
\text { Bill payments } 8.2 \% \\
\text { Airtime top-up 6.6\% } \\
\text { Mobile-to-bank 3.9\% } \\
\text { Off-net transfer 0\% } \\
\text { International } \\
\text { remittances } 0 \%\end{array}$ & $\begin{array}{l}\text { Cash-out } 73.8 \% \\
\text { Bill payments } 15.3 \% \\
\text { Airtime top-up } 4.5 \% \\
\text { Mobile-to-bank } 5.4 \% \\
\text { Off-net transfer 0.4\% } \\
\text { International } \\
\text { remittances } 0.7 \%\end{array}$ \\
\hline \multicolumn{2}{|c|}{$\begin{array}{l}\text { Bulk disbursements have nearly doubled as a \% } \\
\text { share of incoming transactions }\end{array}$} & \multicolumn{2}{|c|}{$\begin{array}{l}\text { Merchant payments now play a larger role in } \\
\text { circulating value }\end{array}$} & \multicolumn{2}{|c|}{$\begin{array}{l}\text { Bill payments and airtime top-ups now make up } \\
\text { more outgoing transactions }\end{array}$} \\
\hline \multicolumn{2}{|c|}{$\begin{array}{l}\text { Total value } 2012 \text { equals } \$ 2.5 \text { billion } \\
\text { Total value } 2017 \text { equals } \$ 12.6 \text { billion }\end{array}$} & \multicolumn{2}{|c|}{$\begin{array}{l}\text { Total value } 2012 \text { equals } \$ 2.1 \text { billion } \\
\text { Total value } 2017 \text { equals } \$ 8.5 \text { billion }\end{array}$} & \multicolumn{2}{|c|}{$\begin{array}{l}\text { Total value } 2012 \text { equals } \$ 2.4 \text { billion } \\
\text { Total value } 2017 \text { equals } \$ 10.4 \text { billion }\end{array}$} \\
\hline
\end{tabular}

Source: GSMA (2017:23)

Table 3 illustrates the shifting of the cash economy to a digital ecosystem. These transactions were able to be recorded thanks to the high level of digitalization between 2012 and 2017. By December 2017 about \$ 12.6 billion went into the global mobile ecosystem. The most used services being: cash-in, cash-out, bill payments, airtime top-up; mobile-to-bank, bankto-wallet, P2P transfer, merchant payment, international remittances, bulk disbursement, and off-net transfers. As more services enter the mobile money industry, its potential for growth increases (GSMA, 2017: 22-23). Also, see, Graph 2.

Graph 2.

Number of Live Mobile Money Services for the Unbanked by Region (2001-2013 Year End) GSMA

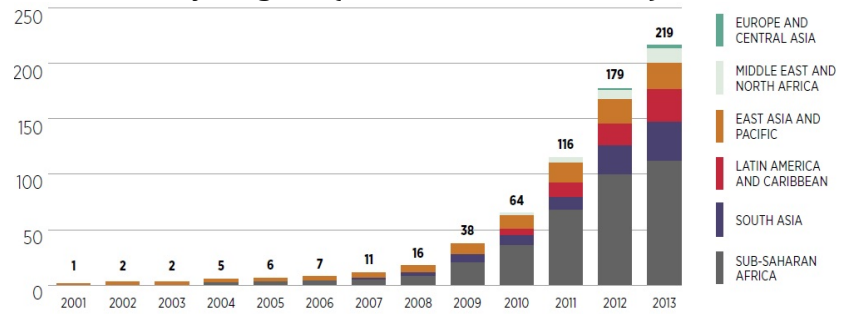

Source: GSMA (2019:9)

In developing countries, the transfer of money (cash-in and cash-out) was the purpose of mobile money when it started. The agents were primarily used to help with these transfers of money. The transfer of money services continues to increase, and so does the agent's number as shown in Graph 3. According to GSMA (2017:26-27), the agent network remains a backbone of mobile money in some countries, and the MNOs spend big to maintain these networks. Digitalization has been used to address this.

Graph 3.

Global Growth of Cash-In and Cash-Out Values and Active Agents

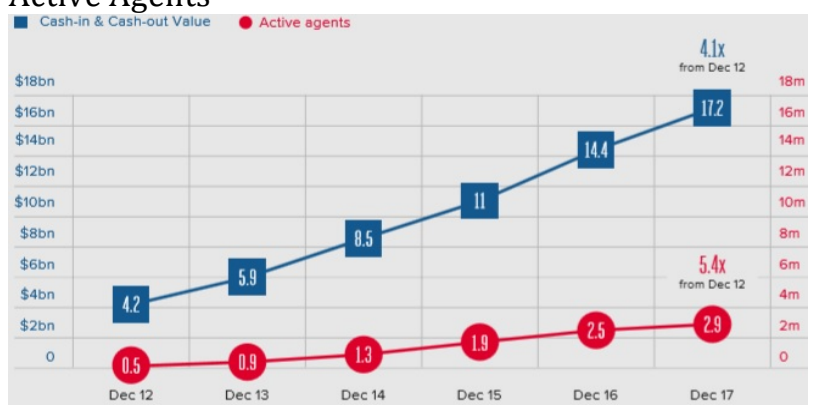

Source: GSMA (2017:27)

\subsection{Mobile Money in the Tanzanian Context}

The FinScope studies estimated that about $60 \%$ of Tanzanians use mobile money services in 2017 (FinScope, 2018). Also, see Graph 4. Only $50 \%$ of Tanzanians used mobile money services in 2013 (FinScope, 2013). From 1961 to 2006, Tanzania had only $11.2 \%$ of adult populations having access to formal financial services (FinScope, 2006). With the successful reintroduction of mobile money in 2008, in 10 years Tanzania had reached $72 \%$ of the adult populations who use formal financial services. The financially excluded people decreased from 54\% in 2006 to 28\% in 2017 (FinScope, 2006; FinScope 2018). 
Graph 4.

Uptake of Formal Financial Services and Uptake of Informal Financial Services

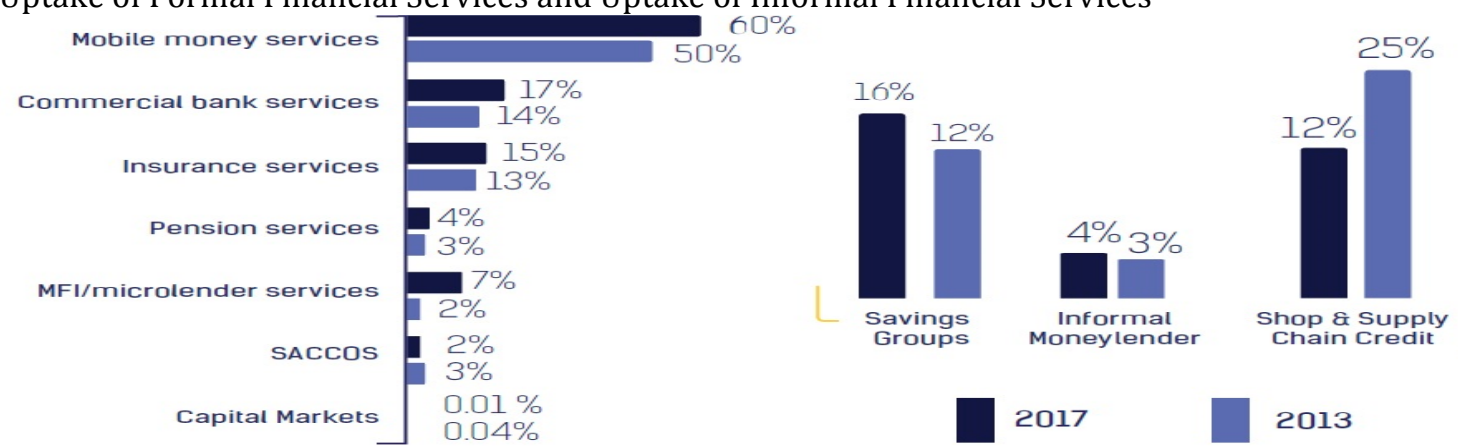

Source: FinScope Tanzania 2017 April-July and FinScope Tanzania 2013

Graphs $5 \mathrm{a}$ and $5 \mathrm{~b}$ below show the difference before and after the introduction of mobile money. In 2006, savings on mobile phones did not have any significance in Tanzania as Graph 5a illustrates. However, between 2013 and 2017 mobile money became one of the main savings instruments in Tanzania, see graph $5 \mathrm{~b}$.

Graph 5a.

How and Where Tanzanians Kept Their Savings in 2006

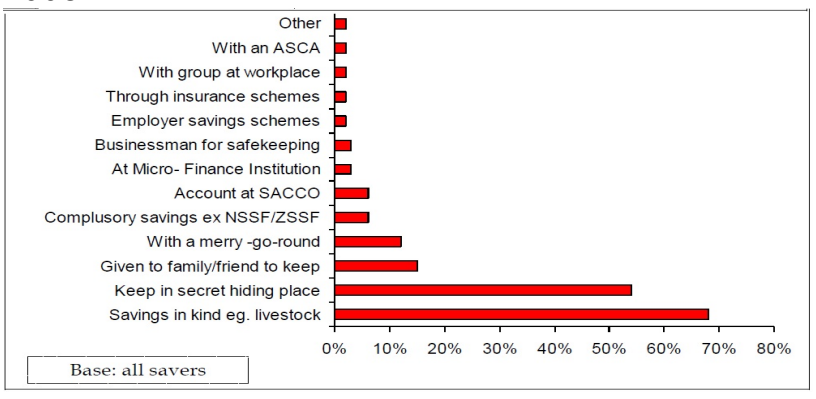

Source: FinScope (2006)

Graph 5b.

Where Did People Saving in 2013 and 2017?

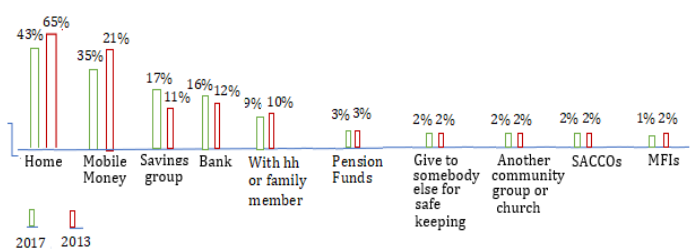

Source: FinScope (2018)

Moreover, sources and trends in borrowing have also started to change. Graphs $6 \mathrm{a}$ and $6 \mathrm{~b}$ illustrate this as shown below. While in 2006, loans came from family/friends, Microfinance Institutions (MFIs) and Savings and Credit Cooperatives (SACCOs), and that the MFIs and SACCOs financed more urban than rural populations, the need for loans was apparently high.

Graph 6a.

Sources of Borrowing by Urban-Rural Population

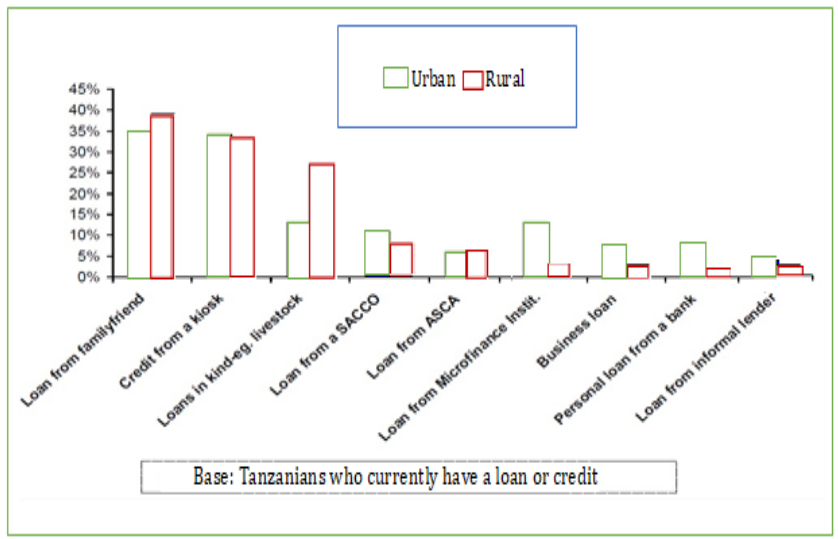

Source: FinScope (2006).

Graph 6b

Where Did They Borrow?

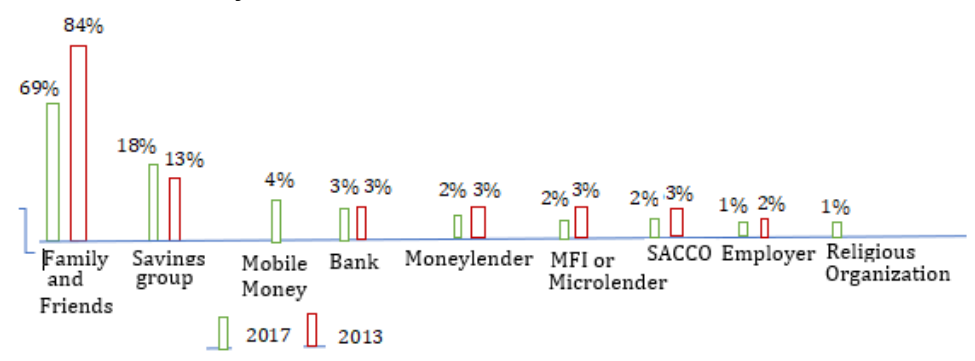

Source: FinScope (2018).

Between 2013 and 2017 (as illustrated in Graph 6b) borrowing for the poor through mobile money started to take off and jumped a little bit above the banking institutions. 
Also, how people keep their accounts active as illustrated in Graph 7.

Graph 7.

Recency of Financial Service Usage

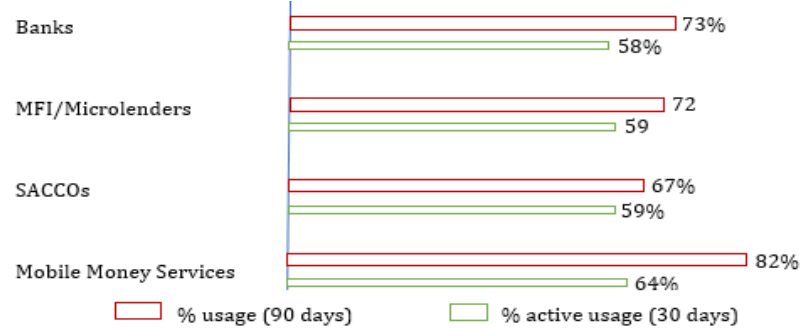

Source: FinScope Tanzania 2017 April - July

Active usage of mobile money accounts surpasses that of bank accounts and other types of accounts, with mobile money active accounts at $64 \%$ and other types of accounts below $60 \%$.

With mobile money competition, mobile banking has also grown between 2009 and 2015 . See Graph 8. Between 2010 and 2012, sluggish growth was recorded.
Graph 8.

Mobile Banking Growth (2009-2015)

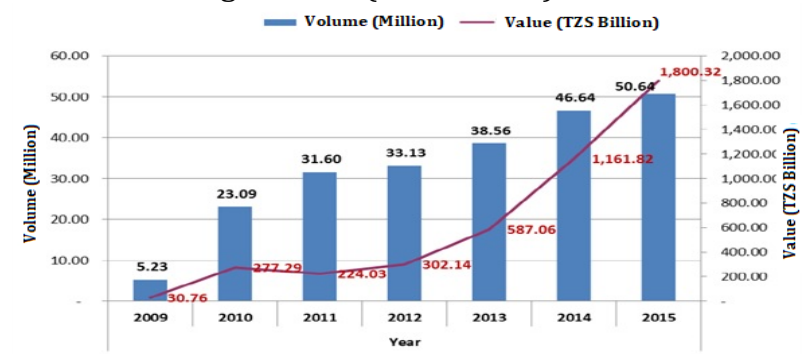

Source: BOT (2017)

However, from 2012 the mobile banking growth has continuously increased. We should not confuse mobile banking and mobile money or mobile payments, hence Graph 9, below, illustrates the trend for mobile payments.

Graph 9 shows rapid growth in mobile payments since 2010 . And Table 4 below presents the registered and active accounts for mobile money.

Graph9.

Mobile Payment Growth (2009-2015)

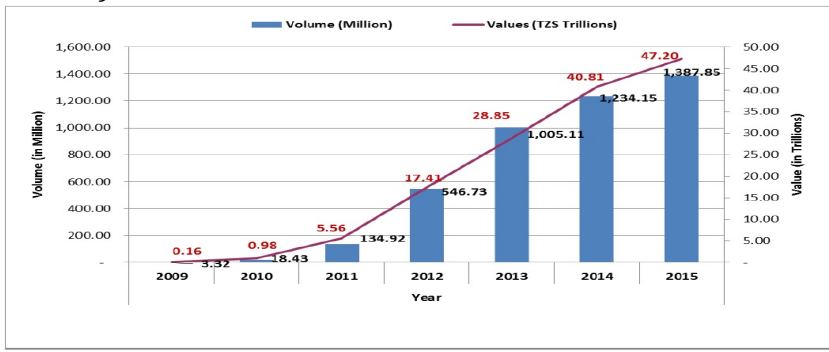

Source: BOT (2017).

Table 4

Mobile Payment Services Statistics

\begin{tabular}{|c|c|c|c|c|c|c|c|c|c|}
\hline & 2008 & 2009 & 2010 & 2011 & 2012 & 2013 & 2014 & 2015 & 2016 \\
\hline $\begin{array}{l}\text { Registered } \\
\text { Accounts }\end{array}$ & 112,000 & $4,192,683$ & $10,663,623$ & $21,184,810$ & $26,871,176$ & $31,830,289$ & $41,380,791$ & $49,356,465$ & $71,245,336$ \\
\hline $\begin{array}{l}\text { Registered } \\
\text { Active Users }\end{array}$ & & & & & $7,872,749$ & $11,016,657$ & $13,856,667$ & $19,793,087$ & $17,025,685$ \\
\hline $\begin{array}{l}\text { Registered } \\
\text { Agents }\end{array}$ & 2,757 & 14,469 & 29,095 & 83,795 & 97,613 & 153,369 & 238,461 & 267,047 & 371,132 \\
\hline $\begin{array}{l}\text { Trust } \\
\text { Accounts } \\
\text { Balance (TZS } \\
\text { billion) }\end{array}$ & & 7.11 & 30.34 & 96.06 & 192.42 & 293.52 & 450.95 & 561.2 & $\begin{array}{r}665.7 \\
\text { billion }\end{array}$ \\
\hline
\end{tabular}

Source: BOT (2017)

There were only 112,000 registered mobile payment accounts in 2008 and about 71,245,336 in 2016, with active accounts reaching $17,025,685$. This is because one person may have two or three registered accounts and one active account.

Mobile service agents also increased from 2,757 in 2018 to 371,132 in 2016 (see Table 4). 
For the trends in electronic payments see Graph 10 below. Mobile money takes the lead.

Graph 10.

Trends in Electronic Payments, 2011-2015 (TZS billions)

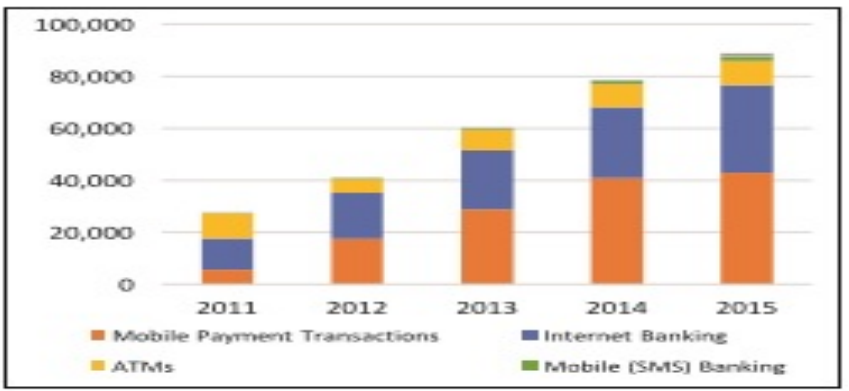

Source: Bank of Tanzania 2016

From this analysis, I argue that mobile money in Tanzania has changed the provision of financial services as it includes more adult populations than the banks and other Financial Institutions (FIs) do. Between 2009 and 2013, FinScope (2013) shows that the percentage of adults with access to financial services increased to 57.4 percent from 15.8 percent, mainly due to the use of non-bank formal financial services, which reflect the uptake in use of mobile money services. Between 2013 and 2017, access to formal financial services increased from $57.4 \%$ to $72 \%$, mobile money providing about $60 \%$ of the formal financial services uptake (FinScope, 2018). There are about five model categories of mobile payments. They are: (i) operator-centric or telcoled model: which uses the mobile operator to deploy mobile payment services independently; (ii) Bank-Centric Model: which uses a bank to deploy mobile payment applications or devices to agents or customers with the required Point-OfSale (POS) acceptance capability; (iii) Collaboration model: involves banks, MNOs and a third trusted party; (iv) Peer-to-Peer model: which involves an independent mobile payment service provider, other than FIs and MNOs, to provide mobile payments (AFI, 2012: 3). Tanzania uses the telco-led model for mobile money, with any third parties such as 'Selcom' and 'Maxicom' facilitating utility payments.

Typical mobile financial service payments adopted by the market in Tanzania include: (i) 'P2P' (Person-to-Person payments): which includes both domestic and international remittances (money transfer); (ii) 'P2B' (Personto-Business payments): which facilitates the purchase of goods and services, bills and utility settlements for water, electricity, TVs, medical expenses, school fees, etc.; (iii) P2G (Person-toGovernment Payments): which include taxes and fees, for instance, road licenses, road tickets, etc.; (iv) B2P (Business-to- Person Payments): which include salary payments and social benefits (BOT, 2017). To regulate mobile money the BOT uses the following regulatory tools: (i) The 2015 National Payment Systems Act; (ii)The 2015 Payment Systems Licensing and Approving Regulations; (iii) The 2015 Electronic Money Regulations (BOT, 2017). To operationalize the regulations, the BOT created the following tools: (i) oversight policy framework; (ii) oversight manual for licensing and approving; (iii) oversight off-site surveillance manual; and (iv) oversight on-site examination manual (BOT, 2017). Before the introduction of these regulatory requirements in 2015, the MNOs required the 'letter of no objection' to operate. They were also required to form separate legal entities that dealt with financial services. The BOT regulated them. The communication aspect of those entities is still under the TCRA.

According to Parkes (2014), the BOT and the TCRA also have a memorandum of understanding (MoU) to help them regulate mobile money services. This (MoU) was for administrative purposes, and it did not give the status of coregulators to the above-mentioned regulating bodies. It was the 2012 'Mobile Payments Regulations' (MPR) that provided a system for regulatory and supervisory coordination between the two bodies.

Table 5 illustrates the Mobile Money Providers in Tanzania and their Market share.

Table 5.

Tanzania Mobile Money Market Share (March 2018)

\begin{tabular}{|l|l|}
\hline \multicolumn{1}{|c|}{ Mobile Money Operator } & \multicolumn{1}{c|}{ Market Share } \\
\hline Vodacom Mpesa & $43 \%$ \\
\hline Tigo Pesa & $36 \%$ \\
\hline Airtel Money & $17 \%$ \\
\hline Halotel Money & $3 \%$ \\
\hline Ezy Pesa & $1 \%$ \\
\hline TTCL & $0.04 \%$ \\
\hline
\end{tabular}

Source: Source: TanzaniaInvest (2018). 
During the time of my fieldwork research in April 2018, there were 6 MNOs in Tanzania and Smart entered the market later. Vodacom MPesa, Airtel Money and TigoPesa are the three biggest MNOs in Tanzania. Halotel Pesa, Zantel EzyPesa, and TTCL Pesa have a small market share.

Following the above explanations of mobile money in Tanzania, the question remains what do mobile money do to increase financial inclusion levels? I will first demonstrate the methodology I am using to answer this question in the next section. Then, I will delineate the theoretical assumptions as well as the qualitative findings to support my claims.

\section{Methodology}

The paper uses interview evidence and documentary methodology, also known as content analysis, employing data collected from credible sources. It also uses interviews that were conducted in Dar-es-Salaam, Tanzania. It took three months to interview about 60 relevant professionals from 35 relevant institutions. As it regards documentary reviews in collecting data, Mogalakwe (2006) and Scott (1990) depict the documentary method as the technique used to categorize, investigate and interpret written documents from private and public sectors. This method is not only reliable and cost-effective but also yields valid findings from official and credible sources used. The researcher used official documents, journal articles, websites of government institutions and other relevant institutions to strengthen his observation on mobile and banking issues as well as on how mobile money moderates the factors of financial exclusion. The methodology is suitable since mobile money and banking sector data are found in these sources.

\section{Theoretical Assumptions and Qualitative Findings: Moderation of the Factors of Financial Exclusion}

In this section, I present the theoretical assumptions and the findings of my research and I argue that mobile money came to resolve the following issues: (i) lack of access to formal financial services to the financially excluded people, which include: (a) the physical barrier in terms of distance that existed between the banks and the customers, therefore, inconvenience of services; (b) the lack of wide scale-adoption of new innovative services to serve the poor; (ii) high costs of formal financial services; (iii) the risk of providing formal financial services to the financially excluded people, therefore, risk management issue.

\subsection{Lack of Access to Formal Financial Services to the Financially Excluded People}

The biggest constraint to financial inclusion or if you want the main factor behind exclusion was first access. You can't give a service if you can't reach the one that you want to serve. And the reasons for challenges in access were very clear, eh one is simply distance, space, and scale. You cannot open a branch where there are five customers. The cost of opening a branch can never be, absorbed by that small number. It means that if you only use the traditional system, there is no way you can go beyond where most of the branches now are. In a district, headquarters, eh small towns upward. So that was the challenge number one (Respondent Kiki).

Respondent Kiki was right. From 1961 to 2006 those who had access to formal financial services were about 9\% (FinScope, 2006). Due to the lack of access, people started using buses to transfer money.

\begin{abstract}
Mobile financial services aided in mobilize funds. Access, people kept their money under the pillow. They were waiting for buses to help them transfer money. To send money to their mothers in the villages, they put money in the envelopes. They gave it to an agent. The agent took it to Dar Express Bus (Respondent City).
\end{abstract}

Access strands 1 and 2 below illustrate that access was an issue with high levels of financial exclusion in 2009 at $55 \%$, and with mobile money, those levels plummeted to $28 \%$ in 2017. 
Access Strand 1.

Access to Financial Services by Categories in 2006

\begin{tabular}{|c|c|c|c|}
\hline Formal & & informal & Excluded \\
\hline $9 \%$ & $2 \%$ & $35 \%$ & $54 \%$ \\
\hline
\end{tabular}

Source: FinScope (2006)

Access Strand 2

Uptake of Financial Services

\begin{tabular}{|c|c|c|c|}
\hline 2017 & $167 \%$ & $486 \%$ & $67 \%$ \\
\cline { 2 - 4 } 2013 & $14 \%$ & $43 \%$ & $16 \%$ \\
\cline { 2 - 4 }
\end{tabular}

Source: FinScope Tanzania 2017 April-July, FinScope Tanzania 2013 and FinScope Tanzania 2009

Graphs 11 and 12 reveal the results of InterMedia Surveys conducted between 2013 and 2017. The Surveys indicated that the growth in access to formal financial services was driven by mobile money (InterMedia, 2017; InterMedia, 2018). Demombynes and Thegeya (2012) also acknowledge the transformation of poor rural households through mobile money that has increased access to essential financial services such as money transfer and saving services.

Graph 11

Registered Users (\% of Tanzanians Adults by Year)

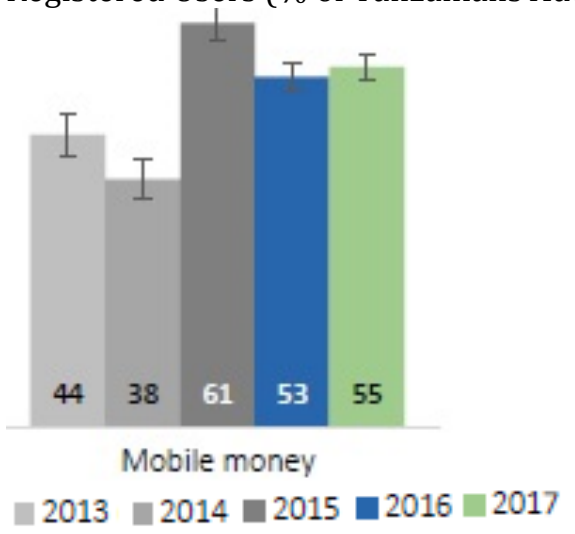

Source: InterMedia (2018:11).
Graph 12

Account Access/Trials (\% of Tanzanians Adults by Year)

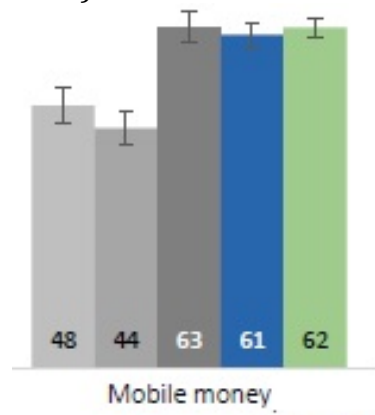

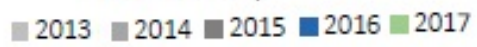

Source: InterMedia (2018).

The data presented in Graphs 11 and 12 help me to argue that mobile money increased access to formal financial services in Tanzania. It reached those people who were unreached by the banks. Hence, it reduced the issues of distance, space, and scale which enhanced financial exclusion. Mobile money moderated the issue of scale as it created six networks to reach the financially unreached. Some researchers provide evidence to show that mobile money offers a solution to resolve the proximity to banking infrastructures 
(Jack and Suri, 2011; Morawczynski and Pickens, 2009; Mbiti and Weil, 2016).

We were able to increase access to people who used formal financial services which was a success, and we were able to increase proximity to financial service providers which was also a success. We were able to meet that... For instance, some people argue that the issue was the proximity to the branches and now you have mobile money so no matter where you are you can do transfers, you can receive money without going to a bank. For instance, issues of cost like I was in the village, and I have to go to town every time I have to put money in the bank. But now with mobile money I can just buy and sell and get my value on the phone without having to transfer and pay for the bus, whatever, so the cost is cut (Respondent Jeru).

To moderate the access barrier mobile money technology was easily diffused to reverse the distance, space, and scale issues. This is in line with the innovation of diffusion theory and the theory of change. Invented in 1962 by Rogers, the innovation of diffusion theory could explain how mobile money diffused among the financially excluded over time. It may also explain the customer's behaviour towards the adoption and non-adoption of new technology (Munyoki et al., 2015). For the financially excluded people, I found that mobile money was appealing to them as it was quick, convenient and easier to use because they used their mobile phones anywhere and at any time. Hence, its diffusion amongst the poor was quicker. Rogers defined users in a graph as innovators, early adopters, early majority, late majority, and laggards. See Graph 13. The Tanzanian situation still shows an upward trend if you fit it in Roger's graph.

\section{Graph 13}

Diffusion of Innovation (Adopter's Classification)

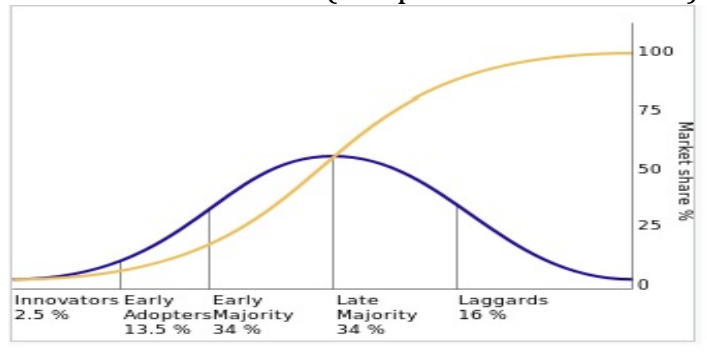

Source:

https://en.wikipedia.org/wiki/Diffusion_of_innovations
Moreover, increased access is supported by the theory of change. Using the theory of change, Leydier (2016:3) argues that mobile money affects savings in three ways. Firstly, mobile money increases income as the volume of money transfers increases due to cheap transfers of money. As a result, the adoption of mobile money helps increase the likelihood of saving behaviour. Secondly, mobile money is a saving product itself and as it scales up, it encourages the use of formal financial services. Thirdly, as more people join mobile money services, mobile money is considered as a bridge towards financial inclusion. Medhi and Ratan (2009) also claim that there are more mobile money account users than there are bank account users across the world.

To conclude on the issue of moderation of lack of access, mobile money is designed to offer access to financially excluded people (Peruta, 2018:155). It is easier to measure the moderation of lack of access through studying: (i) mobile and bank accounts (Toxopeus and Lensink, 2007; De Koker and Jentzsch, 2013; InterMedia, 2017; InterMedia, 2018); (ii) availability of bank and mobile money services (Amidzic et al, 2014; Beck et al., 2008; Demirguc and Klapper, 2012; Sarma, 2008; Sarma, 2012; InterMedia, 2017; InterMedia, 2018). Refer to the provided statistics throughout this article.

\subsection{High Costs of Formal Financial Services}

The second factor of financial exclusion and also the primary challenge to financial inclusion was the high cost of formal financial services. Before the advent of mobile money, the costs of accessing formal financial services were so high that the would-be users of the formal financial system were not ready to absorb the cost of the service which was exorbitant. Maurer (2011) argues that mobile money fights against banking exclusion. Other researchers have also demonstrated that mobile money provides a solution for the high price of banking services (Donavan, 2012; Morawczynski and Pickens, 2009; Arestoff and Venet, 2013; Mbiti and Weil, 2016). Hence, one thing for sure that opened the door for the inclusion of the poor was technology.

According to Aker et al. (2014), electronic payment systems are more efficient than 
traditional banking services as they reduce transaction costs and time. Technology ensured that one could reach the customers without investing much in brick-and-mortar branches. McKay and Pickens (2010) studied 18 branchless service providers in 10 countries and found that they were $19 \%$ cheaper than the banks and that their services were more inclusive. This finding matches my findings in Tanzania. Also, respondent Kiki asserted:

... to start with the cost of the transfer, the cost of transactions, went way down, typically before it was almost like about 10 cents to a dollar about $10 \%$. After the introduction of mobile money, it went down to 1 cent to a dollar. It is one percent. So, this is affordable. So, it is access, affordability. These were the two main, eh, targets that were being resolved by the introduction of this technology. So, I think that's number one as to what actually occurred (Respondent Kiki).

Mobile money systems can easily be linked to other financial systems. And the concept of open systems theory can be used to link mobile money with other systems to further cut down prices. An open system is a system that has external interactions (also see: Bertalanffy, 1968). With open systems theory, one could understand how mobile money was influenced by its environment and other players in the financial sector (Dahlberg et al., 2008). The system could also mean various networks. Dahlberg et al. (2008) have used the open systems theory to also study mobile money. According to the World Bank (2014), increasing mobile phone network adoption and penetration, its affordability and lack of affordable alternatives in the financial system, as well as the higher conventional banking account fees, have helped mobile money to include more the financially unreached populations. Moreover, the World Bank (2002) claim that the poor depend heavily on existing social networks to transact and trade in developing markets. Hence, the link between mobile money and other financial services, networks and systems is imperative. In addition, USAID (2012) sees mobile money as a costeffective technology and more efficient when compared to cash payments.

CGAP (2013) acknowledges the fact that the poor use their closed networks of relatives and open networks of friends to learn more about the use of mobile phones for saving and transferring money. As saving and money transfers can be expensive, mobile money becomes the most efficient means for saving and transferring money:

I was interested, so I asked to visit the villages to have a couple of sessions with people, just to know why they don't opt to actually put their money in a bank account instead of keeping it in their phones. Do you know what their answer was? One said, if you put your money in a bank account, every end of the month, even if you did not use that account, the balance has reduced. Because, you know, ledger costs, etc. Eh. But, if you saved by using a mobile money account, that was what they said, even before the profit-sharing, your money was intact. Well, that was a big difference. Now, I am sure if you ask them again, and on top of that I also still earn some profits on this mobile money side (Respondent Kiki).

Furthermore, the interoperability of mobile money systems also reduced the cost of mobile money services.

\subsubsection{Interoperability}

Interoperability enables mobile money services to interact with the benefits of customers and operators. A customer owning a mobile account with an MNO can make transfers from his account to another account with a different MNO. The first interoperability agreement in Tanzania was signed in 2014. According to Di Castri (2013b), interoperability has the following benefits: (i) it makes commercial sense for providers, and it creates value for customers; (ii) it helps share regulatory risks; (iii) it lowers the costs of financial services, and it increases customer's choices; (iv) it increases competition and break dominant positions; (v) it removes the need for individuals to own and manage multiple SIM cards.

Metcalfe's theory explains the importance of interoperability:

There is a correlation saying that the value of a network is exponentially based on the number of players in a network. Going with that theory, the more players you have connected, the value 
of that network grows. Theoretically, the volume of that network should grow. And with higher volumes, you should be able to run those transactions at a very low cost. And when you run those transactions at a very low cost, that is when you will be able to include people that are not in the system because of unaffordable costs. If you look at it from that angle, yes, interoperability will bring more volume. Yes, it's true, but first, the pricing has to be right (Respondent Waziri).

Furthermore, Moore's law has been used to help reduce the costs of technology. According to Oxford (2009), Moore's law states that the number of transistors packed into a given unit of space will roughly double every two years. The law has been used to develop new technologies and to improve the existing technologies (The Economist, 2015). Literature suggests that Metcalfe's law and Moore's Law together provide us with the best basis to understand how networks lower prices of services. Put together the two laws explain the supply side and demand side of services. On the supply side, the diseconomies of scale may lead to the expansion in the size of networks which may increase costs (Yoo, 2015:88) quoting Mann (2000)). Moore's law claims that digitization reduces costs and can reduce the increases in costs. If the increase in costs produced by the expansion in size remains lower than the reduction in costs related to Moore's law, costs should remain manageable even network continues to grow (Yoo (2015:88) quoting Metcalfe (2013)).

On the demand side, Metcalfe's law says that the number of potential connections increases quadratically with the number of nodes. To the extent that expanding the number of potential connections increases the value of a network. The Metcalfe's law provides another reason for believing that growth in network size will be automatically beneficial (Yoo, 2015:88).

Hence, if the MNOs manage to get the pricing right, they will be able to involve those who have been excluded because of pricing. However, they may not be able to include those people who are excluded because the market has the wrong products for them or because they do not have the right to insurance, and so forth. In sections 4.2.1.1 and 4.2.1.2 I will explain the application of interoperability to bring the costs down in Tanzania. I argue that interoperability has been allowed in Tanzania for 'exclusivity' and 'nonexclusivity' reasons.

\subsubsection{Exclusivity and Non-Exclusivity Reasons for Interoperability}

When mobile money started in Tanzania, MPesa had its agents. Airtel had its agents. And so forth. Later on, Tigo also came with its agents. The problem was that the volume of their business through the agents was low. The MPesa agents were restricted to deal with MPesa customers. Likewise, the other agents dealt with their MNOs only. To remove this aspect of exclusivity, the 'non-exclusive' interoperable system was initiated.

We call the first stage: 'non-exclusivity'. You know when we started if the agent served MPesa, he only worked for MPesa. Airtel needed their own agents. The MPesa agent could not serve Airtel. So, the first major step we took was to remove exclusivity. Now, the agent can serve any number of mobile money services eh that $\mathrm{s} /$ he has a contract with. You will see that the agent has advertisements from various MNOs. He serves MPesa. He serves Airtel. He serves another MNO. That's step number one. There still existed two significant costs incurred by the customer. When you sent money as an MPesa client, and the receiver is from Airtel, it was sent as a message. He had to go to the sender's network through their agent to receive cash. The receiver paid fees. If he wanted to send the same money elsewhere, as it was not the end process, he needed to go to an Airtel agent to buy electronic money and put it in his wallet as a balance. So, the cost of time. There are fees because you have to pay for both services (Respondent Kiki).

In 2014, an interoperability agreement between the BOT, two banks, and all four MNOs (Tigo, Airtel, Zantel, and Vodacom) was reached as it laid the foundation for different levels of interoperability. The main levels of interoperability in Tanzania during the time of my field research were: (i) 'agent level'; (ii) 'wallet-towallet level'; (iii) 'wallet-to-other platforms'.

At the agent level, the removal of 'exclusivity' meant that no agent was exclusive to one 
operator. Hence, a Mpesa agent, likewise an Airtel agent could serve other MNOs. This is the reason why an agent today serves more than one MNO. This has increased the scale and volume of business and is in line with Metcalfe's theory. And if the agent rented a place for his business, now he covers a much bigger business than earlier. Meanwhile, when a non-Mpesa customer receives money from an MPesa customer, the agent is likely to transfer the money from an MPesa account to a non-Mpesa account. The non-Mpesa customer will be able to buy Airtel units and put the balance on his Airtel phone. Before these arrangements, a customer needed to leave the agent and walk a distance to find an Airtel agent, before he could buy the Airtel units. This is the agent level interoperability.

You know interoperability is something you can only convince the MNOs to do. There is only one reason for this. The one who puts 'minara' (towers) has already suffered a cost. And the prime movers always get their benefit from the fact that they will enjoy renting for a while. Later on, Airtel and only with its small system, Tigo were also starting. Mpesa, who is the giant has spread in many locations because he had massive investments. Now you tell them, ahhaa Tigo, now Tigo's customer can also send money to their system. So, what happens in interoperability is to remove these two costs, and if I send you money from my MPesa account it comes straight to you, and it reflects in your balance as an Airtel's customer. No agent is needed for this transfer. You don't have to go, nor do you have to get charged. Now, the thing was how do you convince the prime movers. (Respondent Kiki).

This situation leads us to the second level of interoperability in Tanzania known as 'Wallet-toWallet' level. My findings confirm that Tanzania was the first in the world to reach this level of interoperability. At this level, a Mpesa customer could send money directly to an Airtel e-wallet:

Before you received an SMS, you were required to cash, and you were charged while cashing out your money. Then you bought the Airtel float and you were charged again. These days, from my Vodacom account it goes straight to your Airtel account. You don't need to visit the agent. You are not charged to cash out. You do not need to buy the Airtel units. This decreased expenses for the user and has also increased business volumes for the operators (Respondent Kiki).

The Wallet-to-Wallet interoperability triggered the banks to rethink about their operations:

So, going with the Metcalfe's theory, if you have a network of two operators, the value of that network is what you could send to and from. I can only send it from Airtel to Tigo. If I bring in Vodacom, TTCL, Zantel, and Halotel, all of a sudden, I have increased or improved. I could send across, then is much more work (Respondent Waziri).

If the pricing is right, the wallet-to-wallet interoperability reduces costs significantly. The banks have tried to use the same theory, but they have failed for a long time due to pricing among other issues:

It is something that banks have been doing for a while and send money from one bank to another bank. Of course, why is it not inclusive? Because the price is not right. The swift will charge you 40 dollars to send money from one bank to another, regardless of the amount, right? ... That's an example, you have an interoperable environment, but it is not inclusive (Respondent Waziri).

Hence, competitive pricing and the right products are key to interoperable systems. The MNOs with affordable services and the right products for the financially excluded people have managed to include more of the financially excluded people in their interoperable systems. Because of the convenience of the mobile money interoperable system, the 'wallet-to-otherplatforms' became the third level of interoperability in Tanzania. It is much more convenient, once a customer receives money in his airtel mobile money account, and he wants to pay for his electricity bills, that is a 'wallet-toother platforms' interoperability. It is between the mobile money provider, the operator, and the service providers. If a customer wants to pay his electricity bill, there are aggregators such as Selcom and Maxicom. They act as intermediaries who receive payments from customers and send them to TANESCO (the national electricity company in Tanzania). 
TANESCO receives the payments and provides the customer with electrical services. That is another stage of that interoperability between the financial service provider and service provider who is ultimate.

Therefore, what has this done. Firstly, it increases convenience. Secondly, it reduces the cost of service. Thirdly, as a result, it grows utilization and the financial services market as a whole. It is a big motivator for the growth of the business, convenience, and reduction of cost (Respondent Kiki).

Graph 14, below, illustrates the growth of an interoperable mobile money market in Tanzania. Interoperability among the MNOs (TigoPesa, Airtel Money, EzyPesa and Vodacom) recorded an upward trend.

Table 14.

MNOs Interoperability Trends

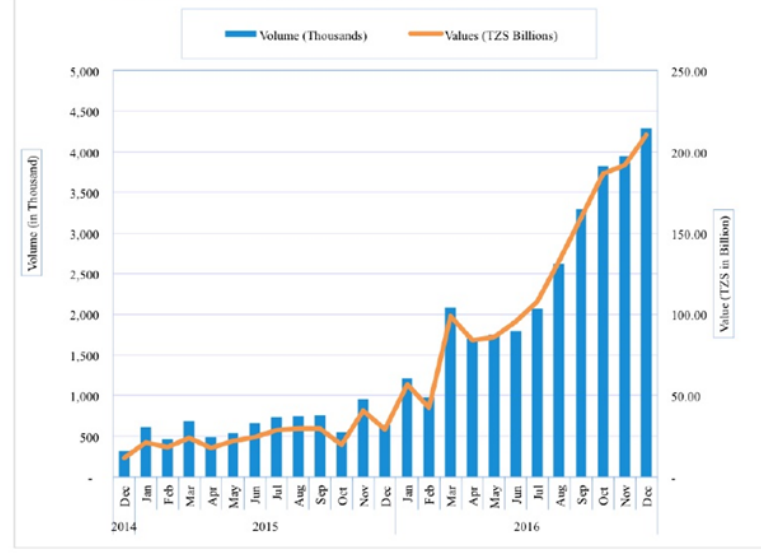

Source: BOT (2017) - Oversight Department.

\subsubsection{Background on Tanzania's Mobile Money Interoperability}

In 2014, an interoperability agreement between the BOT, two banks, and all four MNOs (Tigo, Vodacom, Zantel, and Halotel) was reached and laid down the foundation for the abovementioned different levels of interoperability. Tigo led the remaining MNOs into an agreement as the MNOs became aware of the challenges facing the mobile money sector, which included: (i) the direct competition for the market share; (ii) the slow-pace growing market; and (iii) latent demand from potential customers' willingness to increase frequency and value of transactions. To overcome all these challenges, in 2013 Airtel, Tigo and Zantel implemented their interoperability scheme, while Vodacom supported the structure, it did not sign up (see Jones-evans, 2016; Musa et al., 2014; Di Castri and Gidvani, 2014 and Borreau and Valletti, 2015). In 2015, Vodacom started discussions to join the interoperability agreement (IFC, 2015) and in 2015 it joined the interoperability agreement to make Tanzania the first African mobile money market with full interoperability for mobile money peer-to-peer (P2P) transfers (Kabendera, 2015). Furthermore, in 2015 'The 2015 National Payment Systems Act', 'The 2015 Electronic Money Regulations' and 'The 2015 Payment Systems Licensing and Approving Regulations' were reinforced to set up the rules of the game.

\subsection{Moderation of Risk by Mobile Money Services}

The risk is the other factor causing financial exclusion that mobile money has been able to moderate. In the financial sector, and for this research, risk can be grouped into: 'financial risk', 'performance risk' and 'privacy risk' (John et al., 2018). While the financial risk may include things such as credit risk, liquidity risk, capital risk, and moral hazard; the performance risk includes things like market risks, business risk, systemic risk, reputational risk and legal risk (Apătăchioae, 2015:38; Rodica, 2011; Piciu, 2013). Meanwhile, the privacy risk includes leaking of information to unrelated third parties (Giovanis et al., 2012). Over time, banks have considered these risks (Apătăchioae, 2015). The poor was considered a financial risk and therefore unbankable because s/he did not have a regular income (Ayres, 1983; Bakhoum, 1989). If $\mathrm{s} /$ he owned a business, the performance of his business was at risk due to his/her inability to navigate through turbulence in his business environment, should they occur. S/he was also a risk in terms of her/his identity as she/he did not have IDs and how to verify his particulars was an issue that could infringe his privacy. More often, the banks did not deal with the poor.

Mishkin (1998) and Stiglitz (1990) claim that transaction costs and information asymmetry which are market imperfections limited access to 
credit for the poor. The poor did not have collateral (Akerlof, 1970) or credit history, and lending to the poor was a risk because the cost of doing so was high. For these reasons, the banks excluded poor people. The MNOs instead were required to open a trust account that could be used to cover liquidity, credit or other risks should they arise. Graph 15, below, illustrates mobile money trust account balances. Those accounts have kept on growing since 2008 keeping the mobile money market stable (BOT, 2016).

\section{Graph 15.}

Bank Deposits and Mobile Money Trust Account Balances (TZS Billion and \% GDP)

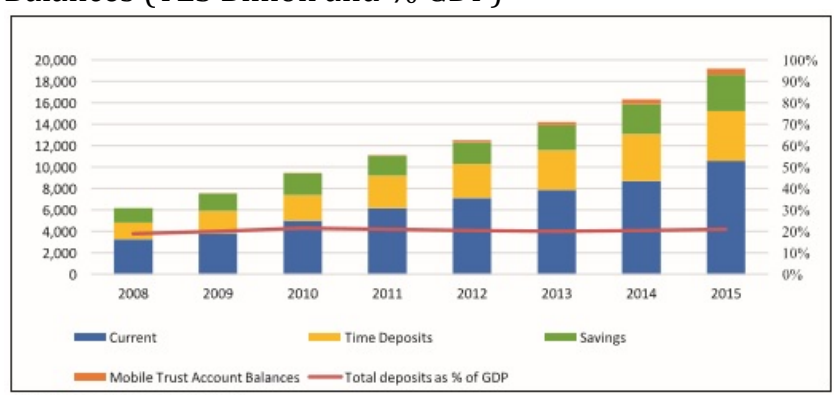

Source: Bank of Tanzania, 2016

Firstly, mobile money providers are purely operating a money transfer system. It is a platform. They don't issue money. For every unit that a customer buys in mobile money, there is a unit which is sitting in a trust account in a bank. So, there is no creation of money. It is also true that they are not taking deposits. This is clear. They are not doing credit. It is clear. What distinguishes banks from other institutions is the fact that they are deposittaking, and per regulations, they are essentially in terms of supervision in managing the risk in relation to the protection of deposit interests. That's the main principle. So those (MNOs) are not taking deposits. There is no risk of exposure to the depositors. They are involved in payment systems, and that's purely a platform. Yeah, purely a platform. And, we told them that it is also true that actually every shilling of the electronic money balance sitting in the e-wallet of someone, they (banks) are the custodians in the trust account, of the equivalent that gives it" (Respondent Kiki).

Traditional banking with siloed channels such as brick-and-mortar branches was neither friendly nor efficient in meeting the poor's needs. The risk of losing money by allowing the poor to use banking services was perceived to be higher. Hence, bank products were not made to meet the needs of the poor (Ayres, 1983; Bakhoum, 1989). On the other hand, mobile money focuses more on the poor (Peruta, 2018:155). It opens accounts for them. Graph 16 below illustrates that the penetration of mobile money accounts is higher than that of bank accounts.

Graph 16.

Account Penetration, 2008-2015 (Millions of Account)

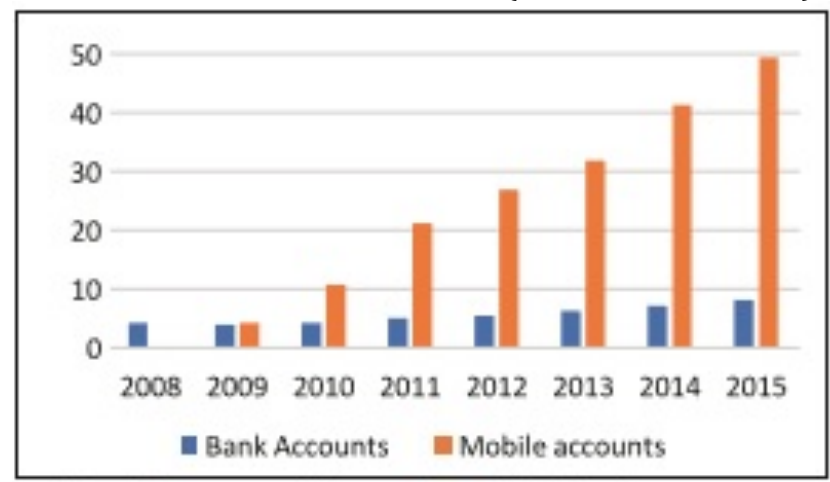

Note: Figures include retail and wholesale accounts. One individual/firm may have multiple accounts.

Source: Bank of Tanzania

Strand 3.

Saving Channel (\% of Adults)

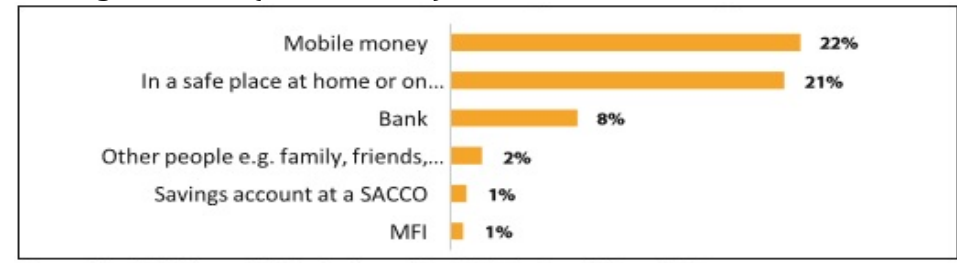

Source: InterMedia Tanzania FII Tracker Survey Wave 3 (September-October 2015)

Moreover, more people now save more in mobile money accounts than they save in banks, see strand 3 above.

Furthermore, mobile money has started to provide microcredit services in collaboration with banks (e.g., Vodacom Mpesa and CBA provide MPawa microloans; Airtel Money with Jumo Microfinance Service provide Timiza microloans, Tigo and Jumo provide Tigo Nivushe microloans). The model is pretty much the same for these services. For M-Pawa loans initial loans are based on the applicant's history of MPesa deposits for 
six months including deposits over time, MPesa usage or airtime purchases. The minimum loan amount for MPesa was 1,000 Tshillings, and the maximum amount was 500,000 Tshillings (Blechman et al., 2017). These loans have been quicker to obtain, and the transfer of funds has been faster as well.

Then there is the risk part. You know the usual system would take many days and uncertainties to do transfers. This (mobile money) was almost instantaneous, eh, and virtually risk-free because there is virtually no timeline between sending and you getting confirmation that it is here. Immediately you push the button the other guy after a few seconds gets feedback that I received it. You know that hugely releases risks. So, it is convenient. It is secure. It is affordable. And those were the three main features that certainly were behind if you want the big push to get from exclusion to that degree of inclusion that you find today. Yeah (Respondent Kiki).

Aghion et al. (2005) argued that small enterprises in developing countries lacked access to credit which led to unsustained underdevelopment. Income inequality and slow growth were a result of a lack of access to financial services. The provision of microloans was a new aspect of mobile money that boosted economic development given that mobile money accounted for about $47 \%$ of the Tanzanian GDP. Everybody knows that credit is important and that it enables the growth of investments. It also provides working capital, and it allows the provision of a whole range of services. That is financial inclusion. It facilitates insurance. It facilitates the treasury. It facilitates student loans. It facilitates education. Hence, development does not have to generate income. There is also the human component of it. It is all facilitated by financial services. Hence, the connection has to be financial services and development, and then financial inclusion is actually what grows financial services. Microcredit services target the poor, and it helps them improve their lives. Here is an example:

Mama Ntilie' (a lady who cooks and sells food on the streets), in the morning she goes to a fish market at Ferry and to the market to buy the ingredients. She uses mobile money and gets micro-credit loans. She will be able to cook and sell. At the end of the business day, she will be able to repay the loans. It becomes a working capital source of those people who cannot get that kind of credit from banks, just because the standards and requirements of the banks are different. They get secured credit. No collateral (Respondent Kiki).

This is how mobile money facilitates credit to low-income people. The risks are kept low. Moreover, MNOs, banks and other third parties recognize that risk management is key to the success of mobile money deployment (Gilman and Joy, 2012: 1-2). Muralidharau et al. (2014) argue that electronic payments are less prone to mistakes, theft, and corruption. Mobile money payments are traceable than cash, and they are regarded to have the potential to reduce risks compared to cash payments (Solin and Zerzan, 2010).

\section{Conclusion}

My findings demonstrate that mobile money has come to resolve three challenges. Firstly, the lack of access to formal financial services, which also includes the moderation of distance and scale. Secondly, moderation of high costs of financial services for the poor or affordability. Thirdly, managing risks and allowing access to more financially excluded people. These are the technical solutions to removing some factors of financial exclusion. Hence, I look at mobile money as a means to an end. It is not by itself as an end. I have shown how mobile money moderated some of the factors of financial exclusion and how it reduces the banking exclusion for the financially excluded people. The following scholars also have written in favor of these arguments (Camner and Sjöblom, 2009; Di Castri, 2013; Merritt, 2011; Hayer and Mas, 2009). Bina and Giaglis (2007) see mobile phones as the best solution for financial inclusion. Those who support this view argue that this is due to location free access, improved control on bank accounts and timely information (Scornavacca and Hoehle, 2007; Krishna and Walsham, 2003; Varshney and Vetter, 2002). 


\section{References}

AFI. (2012). Guideline Note - Mobile Financial Services: Basic Terminology. Bangkok: Alliance for Financial Inclusion.

Aghion, P. et al. (2005). 'The Effect of Financial Development on Convergence: Theory and Evidence', Quarterly Journal of Economics, 120(1): 173-222.

Aker, J. et al. (2014). 'Payment Mechanism and Anti-Poverty Programmes: Evidence from a Mobile Money Cash Transfer Experiment in Niger Centre for Global Development'. Working Paper 268.

Akerlof, G. (1970). 'The market for 'lemons': Quality uncertainty and the market mechanism', Quarterly Journal of Economics, 84, 488-500. doi:10.2307/1879431

Amidzic, G. et al. (2014). 'Assessing Countries' Financial Inclusion Standing: New Composite Index', IMF Working Paper WP/14/36. Washington DC: International Monetary Fund.

Apătăchioae, A. (2015). 'The Banking Risks and Their Regulation', Procedia Economics and Finance, 20: 3543.

Arestoff, F. and Venet, B. (2013). 'Learning to Walk Before You Run: Financial Behaviour and Mobile Banking in Madagascar'. Document de Travail DT/2013-09. Paris: UMT.

Aron, J. (2018). 'Mobile Money and the Economy: A Review of the Evidence', The World Bank Research Observer, 33(2): 135-188.

Ayres, R. (1983). Banking on the Poor: The World Bank and the World Poverty. Cambridge, Mass: MIT Press. Backhoum, I. (1989). Banking the Unbankable: Bringing Credit to the Poor. London: Panos.

Bank of Tanzania. (2016). Directorate of Banking Supervision - Annual Report 2015. Dar es Salaam: Bank of Tanzania.

BOT. (2017). 'The Evolution of Digital Financial Services Ecosystem and its Oversight'. A Presentation by James A. Masoy, Manager, Oversight and Policy Department - National Payment System Directorate. Bank of Tanzania, March 2017.

Beck, T. et al. (2008). 'Banking Services for Everyone? Barriers to Bank Access and the Use Around the World', The World Bank Economic Review, 22(3):397-430.

Bertalanffy, L. (1968). General System Theory. New York: George Braziller.

Bina, M. and Giaglis, G. (2007). 'Perceived Value and Usage Patterns of Mobile Data Services: A CrossCultural Study", Electronic Markets, 17: 241-252.

Bindo, R. and Hasnain, S. (2015). Mobile Money: Choosing a Technical Model for A2A Interoperability: Lessons from Tanzania and Pakistan. London: GSMA. Also Available at: http://www.gsma.com/mobilefordevelopment/wpcontent/uploads/2016/01/2015_GSMA_Choos ing-a-technical-model-for-A2Ainteroperability_Lessons-from-Tanzania-and-Pakistan.pdf Accessed on May 16th, 2017.

BIS. (2015). Payment aspects of financial inclusion. World Bank: Consultative Report.

Blechman, J. et al. (2017). 'Competition Dynamics in Mobile Money Markets in Tanzania'. Working Paper 22/2017. Johannesburg: University of Johannesburg.

Bourreau, M. and Valletti, T. (2015). 'Enabling Digital Financial Inclusion through Improvements in Competition and Interoperability: What Works and What Doesn't?' CGD Policy Paper 065. Washington, D.C.: Center for Global Development. Available online at: http://www.cgdev.org/sites/default/files/CGD-Policy-Paper-65-Bourreau-Valletti-MobileBanking.pdf Accessed on August 1st, 2017.

Camner, G. and Sjöblom, E. (2009). Can the Success of MPesa be Repeated? A Review of Implementations in Kenya and Tanzania. Nairobi: Valuable Bits.

CGAP. (2013). The Power of Social Networks to Drive Mobile Money Adoption. Available at: https://realimpactanalytics.com/content/data-cases/poverty-alleviation-case-power-of-socialnetworks-201303.pdf Downloaded on March 30th, 2019.

Dahlberg, T. et al. (2008). 'Past, Present and Future of Mobile Payments Research: A Literature Review', Electronic Commerce Research and Applications, 7(2):165-181. 
De Koker, L. and Jentzsch, N. (2018). 'Financial Inclusion and Financial Integrity: Aligned Incentives?' World Development, 44: 267-280.

Demirguc-Kunt, A. and Klapper, L. (2012). 'Measuring Financial Inclusion: The Global Findex Database'. Policy Research Working Paper WPS 6025. Washington DC: World Bank.

Demombynes, G. and Thegeya, A. (2012). 'Kenya's Mobile Revolution and the Promise of Mobile Savings'. World Bank Policy Research Working Paper No. 5988. Washington DC: World Bank.

Di Castri, S. (2013). 'Enabling Mobile Money Policies in Sri Lanka. The Rise of eZ Cash': Mobile Money for the Unbanked. London: GSMA.

Di Castri, S. (2013b). Mobile Money: Enabling Regulatory Solutions. London: GSMA.

Di Castri, S. and Gidvani, L. (2014). Enabling Mobile Money Policies in Tanzania: A Test and Learn" Approach to Enabling Market-Led Digital Financial Services. London: GSMA. Also Available at http://www.gsma.com/mobilefordevelopment/wpcontent/uploads/2014/03/Tanzania-

Enabling-Mobile-Money-Policies.pdf Accessed on August 1st, 2017.

Donavan, K. (2012). 'Mobile Money for Financial Inclusion', Information and Communication for Development, 61: 61-73.

Donner, J. (2008). 'Research Approaches to Mobile Use in the Developing World: A Review of the Literature', The Information Society, 24:140-159.

FinScope. (2006). FinScope E-book. Dar es Salaam: Financial Sector Deepening Trust (FSDT).

FinScope. (2009). FinScope Survey: The Demand for, and Barriers to Accessing Financial Services in Tanzania. Dare es Salaam: Financial Sector Deepening Trust (FSDT).

FinScope. (2013a). FinScope Tanzania 2013. Dar es Salaam: Tanzania Deepening Trust Fund (FSDT).

FinScope. (2013b). FinScope Tanzania 2013 Summary Report. Also available at: http://www.fsdt.or.tz//wp-content/uploads/2016/05/FinScope-Brochure-2013-Summary.pdf Accessed on March 21st, 2017.

FinScope Tanzania (2017). FinScope Tanzania: Insights that Drive Innovation. Dar es Salaam: Tanzania Deepening Trust Fund.

FinScope. (2018). FinScope Tanzania: Insights that Drive Innovation. Dar es Salaam: Tanzania Deepening Trust Fund.

Flores, E. et al. (2011). 'The Development of Mobile money Systems'. CDE Paper No. 256. Lomas de Data Fe: CDE.

Ghazizadeh, S. (2012). Acceptance Theory on Mobile Services and Applications. Vasa Yrkeshögskola University of Applied Sciences.

Gilman, L. and Joyce, M. (2012). Mobile Money for the Unbanked: Managing Risk Fraud in Mobile Money. London: GSMA.

Giovanis, A. (2012). 'An Extension of TAM Model with IDT and Security/Privacy Risk in the Adoption of Internet Banking Services in Greece', EuroMed Journal of Business, 7(1) 24-53.

GSMA. (2013). Mobile Money: The Opportunity for India. London: GSMA.

GSMA. (2016). State of the Industry Report on Mobile Money - Decade Edition: 2006-2016. London: GSMA Head Office.

GSMA. (2016b). Mobile Money Regulation: ITU Arab Regional Workshop on Financial Inclusion: Session 5 - harmonized Regulatory Framework of the Digital Financial Services, 26th August 2016. Also Available on: https://www.itu.int/en/ITU-D/RegionalPresence/ArabStates/Documents/events/2016/DFI/Pre/GSMA_\%20ITU_Arab\%20States_25 \%20August\%202016_BM.pdf on July 23rd, 2016.

GSMA. (2017). The State of Industry Report on Mobile Money. London; GSMA Head Office.

GSMA. (2018). The Mobile Money Economy 2018. London: GSMA Head Office.

Heyer, A. and Mas. I. (2009). Mobile Money for the Unbanked: Seeking Fertile Grounds for Mobile Money. London: GSMA.

IFC. (2015). Achieving Interoperability in Mobile Financial Services: Tanzania Case Study. Washington, D.C.: International Finance Corporation. Also Available Online at: 
http://www.ifc.org/wps/wcm/connect/8d518d004799ebf1bb8fff299ede9589/IFC+Tanzania+Ca se+study+10_03_2015.pdf?MOD=AJPERES Accessed on August 1st, 2017.

InterMedia. (2014). Digital Pathways to Financial Inclusion: Findings from the Nationally Representative FII Tracker Survey in Tanzania (Wave 1), Focus Group Discussions with Lapsed Users and Nonusers of Mobile Money, and Mobile Money Agent Research. Nairobi: InterMedia and Bill \& Melinda Gates Foundation.

InterMedia. (2017). Tanzania: Wave 4 Report FII Tracker Survey Conducted August - September 2016. Nairobi: InterMedia and Bill \& Melinda Gates Foundation.

InterMedia. (2018). Tanzania. Wave 5 Report - Fifth Annual FII Tracker Survey Conducted July - August 2017. Nairobi: InterMedia and Bill \& Melinda Gates Foundation.

Jack, W. and Suri, T. (2011). 'Mobile Money: The Economics of MPesa'. NBER Working Paper No. 16721. Massachusetts: National Bureau of Economic Research.

John, E. et al. (2018). 'The Influence of Perceived Risk on the Uptake of Mobile Money Services by SMEs Operations in Karagwe District, Tanzania', International Journal of Advanced Engineering, Management and Science (IJARMS), 4(9): 703-712.

Jones-Evans, S. (2016). 'The Tortoise and the Hare: The Different Ways to Run the Race for Financial Inclusion: What Has Driven the Growth of Mobile Money in Tanzania and Why is its Path So Different to That of Kenya'. Dissertation for the Degree of MSC International Development. Bath: The University of Bath.

Kabendera, E. (2015). Vodacom Joins Tanzania Telcos in Cross-Network Mobile Money Transfer. Also Available at: http://www.theeastafrican.co.ke/business/Vodacom-to-allowcross- networkmobile-money-transfer-/-/2560/2635342/-/aafnfrz/-/index.html Accessed on August 1st, 2017.

Krishna, S. and Walsham, G. (2005). 'Implementing Public Information Systems in Developing Countries: Learning from a Success Story', Information Technology for Development, 11: 123-140.

Leydier, B. (2016). Technology and Financial Inclusion: An Analysis of Mobile Money Usage and Savings Behaviour in Kenya Households'. Master's Degree Thesis. Washington DC: University of Georgetown.

Mann, C. (2000). The End of Moore's Law? MIT Tech. Rev., May-June 2000. At 45, 46.

Maurer, B. (2011). 'Afterward - Mobile Money, Money Magic, Purse Limits and Pins: Tracing Monetary Pragmatics', Journal of Cultural Economy, 4(3):349-359.

Mbiti, I. and Weil. D. (2016). 'Mobile Banking: The Impact of MPesa in Kenya. In Edwards, S. et al. (Ed.). African Successes. Vol. 3. Chicago: University of Chicago Press. Pp. 247-293.

McKay, C. and Pickens, M. (2010). “Who's Served? At What Price? What's Next?' CGAP Focus Note 66. Washington DC: World Bank Group.

Medhi, I. and Ratan, A. (2009). 'Mobile Banking and Usage by Low-Literate, Low-Income Users in the Developing World. In Aykin, N. (Ed.). Internationalization Design and Global Development. Heidelberg: Springer. Pp. 485-494.

Merritt, C. (2011). 'Mobile Money Transfer Services: The Next Phase in the Evolution in Person-to-Person Payments', Journal of Payments Strategy and Systems, 5(2): 143-160.

Metcalfe, B. (2013). Metcalfe's Law after 40 Years of Ethernet, COMPUTER, DEC. 2013, AT 26, 31, Bob Metcalfe's Law: A Network Becomes More Valuable as It Reaches More Users, INFOWORLD, Oct. 2, 1995 , at $53,53$.

Mishkin, F. (1998). 'International Capital Movements, Financial Volatility, and Financial Instability', NBER Working Paper 6390. Cambridge: National Bureau of Economic Research.

Mogalakwe, M. (2006). 'The Use of Documentary Research Method in Social Research', African Sociological Review, 10(1): 221-230.

Morawczynski, 0. and Pickens, M. (2009). 'Poor People Using Mobile Money Services: Observation on Customer Usage and Impact from MPesa'. CGAP Brief. Washington DC: World Bank Group.

Munyoki, K. et al. (2015). 'Effect of Mobile Banking on the Financial Performance of Banking Institutions in Kenya', The Strategic Journal of Business and Change Management, 2(98):1440-1457. 
Muralidharau, K. et al. (2014). 'Building State Capacity: Evidence from Biometric Smart Cards in India'. Paper No. 19999. Massachusetts: National Bureau of Economic Research.

Musa, O. et al. (2014). Is Tanzania Ready for Interoperability in Mobile Money? Also Available at: http://www.cgap.org/blog/tanzania-ready-interoperability-mobile-money Accessed on August 1 st, 2017.

Oxford. (2009). A Dictionary of Physics. 6th Edition. Oxford: Oxford University Press.

Parkes, T. (2014). Mobile Financial Services in Tanzania: The Current and Future Status of the Legal and Regulatory Framework. Also Available Online at: http://www.lexology.com/library/detail.aspx?g=99da90fe-780e-4238-b236-d61d038955de Accessed on August, 1st, 2017.

Peruta, M. (2018). 'Adoption of Mobile Money and Financial Inclusion: A Macroeconomic Approach Through Cluster Analysis', Economics of Innovation and New Technology, 27(2): 154-173.

Piciu, G. (2013). 'Banking Risks in a Global Economy', Financial Studies, 17(1):47-57.

Rodica, T. (2011). 'The Credit Risk Component of the Banking Risks', Annals of the University of Oradea: Economic Science, 1(2): 430-437.

Sarma, M. (2008). 'Index of Financial Inclusion'. New Delhi Working Papers. New Delhi: Indian Council for Research on International Economic Relations.

Sarma, M. (2012). 'Index for Financial Inclusion'. A Measure of Financial Sector Inclusiveness', Berlin Working Papers on Money, Finance, Trade and Development 07/2012.

Scornavacca, E. and Hoehle, H. (2007). 'Mobile Banking in Germany: A Strategic Perspective', International Journal of Electronic Finance, 1: 304-320.

Scott, J. (1990). A Matter of Record, Documentary Sources in Social Research. Cambridge: Polity Press.

Solin, M. and Zerzan, A. (2010). 'Mobile Money for the Unbanked: Mobile Money - Methodology for Assessing Money Laundering and Terrorist Financing Risks'. GSMA Discussion Paper. London: GSMA.

Stiglitz, J. (1990). 'Peer Monitoring and Credit Markets', World Bank Economic Review, 4(3): 351-366.

TanzaniaInvest. (2018). Tanzania Mobile Money Transaction Double Over 1 Year. Available at: https://www.tanzaniainvest.com/telecoms/mobile-money-transactions-2017-2018 Downloaded on March 30th, 2019.

The Economist. (2015). Beyond Moore's Law. May 25th, 2015. Also Available at: https://www.economist.com/science-and-technology/2015/05/26/beyond-moores-law Downloaded on December 1st, 2018.

Toxopeus, H. and Lensink, R. (2007). 'Remittances and Financial Inclusion in Development'. WIDER Research Paper 2007/49.

UNCTAD. (2012). Mobile Money: For Business Development in the East African Community. A Comparative Study of Existing Platforms and Regulations. Geneva: United Nations Conference on Trade and Development.

USAID. (2010). 'Using Mobile Money: Mobile Banking to Enhance Agriculture in Africa'. Brief Paper. Available https://ictworks.org/sites/default/files/uploaded_pics/2011/FACET_MobileMoney_FINAL12202 010.pdf Downloaded on March 30th, 2019.

USAID. (2012). Mission Critical: Enabling Digital Payment for Development. A USAID Opportunity Brief. Washington DC: USAID.

Varshney, U. and Vetter, R. (2002). 'Mobile Commerce: Framework, Applications and Networking Support', Mobile Networks and Applications, 7: 185-198.

World Bank. (2002). World Bank Development Report: Building Institutions for Markets. Washington DC: World Bank.

World Bank. (2014). 'A Survey on Access to and Use of Financial Services in 152 Countries Around the World'. The Global Findex Database. Washington DC: World Bank. 
Yoo, C. (2015). 'Moore's Law and Metcalfe's Law, and the Theory of Optimal Interoperability'. Research Paper 16-7. University of Pennsylvania: Institute for Law and Economics. Also Available at https://poseidon01.ssrn.com/delivery.php?ID=641117074119117074091018093091085024016 0730270270750621010050940220781251021121220110961000630450530980090890941011 0302909901805902100902303608908510002908009207903504008010406511900310203000 $1127008083026127071094100065083123031075107103126071071024 \& E X T=p d f$

Downloaded on November 25th, 2018. 